\title{
Obesity, Weight Stigma and Discrimination
}

\author{
Sarah E Jackson*
}

Department of Epidemiology and Public Health, University College London, London, UK

${ }^{*}$ Corresponding author: Sarah E Jackson, Department of Epidemiology and Public Health, University College London, London, UK, Tel: 02076795634; E-mail: s.e.jackson@ucl.ac.uk

Received date: June 15, 2016; Accepted date: June 15, 2016; Published date: June 20, 2016

Citation: Jackson SE (2016) Obesity, Weight Stigma and Discrimination. J Obes Eat Disord 2: 3. doi: 10.4172/2471-8203.100006

Copyright: (c) 2016, Sarah E Jackson. This is an open-access article distributed under the terms of the Creative Commons Attribution License, which permits unrestricted use, distribution, and reproduction in any medium, provided the original author and source are credited.

\section{Editorial}

Rises in obesity prevalence over recent decades have corresponded with increasing stigmatisation of, and discrimination against, individuals living with obesity. Widespread stereotypes characterise people with obesity as lazy, less competent, lacking in self-discipline, non-compliant, sloppy, and worthless [1-4]. These stereotypes are highly prevalent and rarely challenged in Western society. Weight bias has been documented among health professionals including doctors, nurses, and psychologists [1,5], and in employers and co-workers [6], teachers [7,8], landlords [9], peers [10], parents [6,11], and children as young as three [12]. As a result, individuals with obesity encounter pervasive prejudice and discrimination across a number of domains, including healthcare, employment, and interpersonal relationships.

Health professionals typically report feeling that treating obesity is professionally unrewarding [13-17]. Among patients with severe obesity awaiting bariatric surgery, 78\% report having always or usually been treated disrespectfully by the medical profession because of their weight [18], while more than $70 \%$ feel that most doctors do not understand how difficult it is to be overweight [19]. In the workplace, stereotypes see $26 \%$ of individuals with moderate obesity (body mass index [BMI] 30-35) and 31\% of those with severe obesity (BMI $\geq 35$ ) being discriminated against as a result of their weight or appearance [20]. People living with obesity report not being hired for jobs, being passed over for promotions, and wrongful termination [21]. Experimental research confirms that job applicants who are overweight are viewed less favourably in hiring and employment decisions [22]. In addition, experimental studies indicate that obesity negatively affects women's dating prospects. One demonstrated that personal advertisements that described a woman seeking a dating partner as "fat", "overweight", "fullfigured", or "obese" were evaluated unfavourably relative to an equivalent advertisement with no weight descriptor [23]. Another found that fewer men responded to a personal advertisement that identified a woman more obese than responded to one in which a woman disclosed having a history of drug addiction [24].
National surveys in the UK and US have highlighted just how widespread issue weight discrimination is. In the English Longitudinal Study of Ageing, $6.6 \%$ of individuals with moderate obesity (BMI 30-35), 24.2\% of those with severe obesity (BMI $35-40$ ) and $34.8 \%$ of those with extreme obesity (BMI $\geq 40$ ) reported having been mistreated because of their weight [25]. In the National Survey for Midlife Development in the United States (MIDUS), lifetime experience of weight discrimination in any of 11 situations (e.g. not being promoted, being provided inferior medical care) was reported by $14.2 \%$ of individuals with moderate obesity (BMI $30-35$ ) and $42.5 \%$ of individuals with severe obesity $(\mathrm{BMI} \geq 35)[26]$. Weight-related discrimination is the fourth most prevalent form of discrimination in the US, after sex, age, and race discrimination [21], and has increased more than any other form of discrimination between 1995 and 2006 [26].

The stigmatisation of obesity has important consequences for health and wellbeing. The psychological consequences are well-documented: people who experience weight stigma and discrimination are at increased risk of depression and anxiety disorders [27-29], low self-esteem and self-acceptance [20,27] and body image dissatisfaction [27,30,31], and report poorer life satisfaction and quality of life [32]. There is also emerging evidence for physiological effects, with weight discrimination having been shown to be related to increased blood pressure [33], chronic inflammation [34], greater disease burden [35], worsening physical health [35], and even increased risk of mortality [36].

There is a common perception that weight discrimination might encourage individuals with obesity to lose weight [37], and this is often used to justify stigmatising and discriminatory behaviour. However, a growing literature suggests the opposite to be true. Studies have demonstrated that independent of $\mathrm{BMI}$, people who experience weight-related discrimination are actually more likely to engage in behaviours that promote the onset and progression of obesity, including disordered eating $[27,38-40]$, refusal to diet $[6,41]$, increased energy intake $[42,43]$, and avoidance of physical activity $[30,44]$, and are more likely to gain weight over time $[45,46]$. As such, in addition to its harmful effects on emotional wellbeing and physical health, weight stigma may contribute to further increases in the prevalence and severity of obesity through a vicious cycle of weight gain and discrimination. 
There is a clear need for efforts to tackle the issue of weight stigma and discrimination in society. There have been calls for legal measures to address weight-based inequities in the same way as those based on other characteristics, such as age, sex and race [47], and recent surveys indicate substantial and growing support for policies and legislation prohibiting weight discrimination $[48,49]$. As researchers in the field of obesity, we should lead by example and not only be respectful of participants in our studies but be conscious to avoid weight stigma in our writing. We should all be mindful of using people-first language for obesity, which puts individuals before the disease (see www.obesityaction.org/weight-bias-andstigma/people-first-language-for-obesity). For example, rather than talking about "obese people" use people-first language such as "people with obesity" or "people living with obesity". This is standard practice in other diseases and if we are to address the problem of weight stigma it is important that obesity be given the same respect.

\section{References}

1. Puhl RM, Brownell KD (2001) Bias, Discrimination, and Obesity. Obesity 9: 788-805.

2. Puhl RM, Brownell KD (2003) Ways of coping with obesity stigma: review and conceptual analysis. Eat Behav 4: 53-78.

3. Puhl RM, Heuer CA (2009) The stigma of obesity: a review and update. Obesity 17: 941-964.

4. Teachman BA, Gapinski KD, Brownell KD, Rawlins M, Jeyaram S (2003) Demonstrations of implicit anti-fat bias: The impact of providing causal information and evoking empathy. Health Psychol 22: 68.

5. Foster GD, Wadden TA, Makris AP, Davidson D, Sanderson RS, et al. (2003) Primary care physicians' attitudes about obesity and its treatment. Obes Res 11: 1168-1177.

6. Puhl RM, Brownell KD (2006) Confronting and coping with weight stigma: an investigation of overweight and obese adults. Obes Silver Spring Md 14: 1802-1815.

7. Bauer KW, Yang YW, Austin SB (2004) "How can we stay healthy when you're throwing all of this in front of us?" Findings from focus groups and interviews in middle schools on environmental influences on nutrition and physical activity. Health Educ Behav 31: $34-46$

8. Greenleaf C, Weiller K (2005) Perceptions of Youth Obesity among Physical Educators. Soc Psychol Educ 8: 407-423.

9. Karris L (1977) Prejudice against obese renters. J Soc Psychol.

10. Latner JD, Stunkard AJ (2003) Getting Worse: The Stigmatization of Obese Children. Obes Res 11: 452-456.

11. Puhl RM, Moss-Racusin CA, Schwartz MB, Brownell KD (2008) Weight stigmatization and bias reduction: perspectives of overweight and obese adults. Health Educ Res 23: 347-358.

12. Cramer P, Steinwert T (1998) Thin is good, fat is bad: How early does it begin? J Appl Dev Psychol 19: 429-451.

13. Bocquier A, Verger P, Basdevant A, Andreotti G, Baretge J, et al. (2005) Overweight and obesity: knowledge, attitudes, and practices of general practitioners in france. Obes Res 13: 787795.
14. Campbell K, Crawford D (2000) Management of obesity: attitudes and practices of Australian dietitians. Int J Obes Relat Metab Disord 24: 701-710.

15. Campbell K, Engel H, Timperio A, Cooper C, Crawford D (2000) Obesity management: Australian general practitioners' attitudes and practices. Obes Res 8: 459-466.

16. Loomis GA, Connolly KP, Clinch CR, Djuric DA (2001) Attitudes and practices of military family physicians regarding obesity. Mil Med 166: 121-125.

17. Thuan J-F, Avignon A (2005) Obesity management: attitudes and practices of French general practitioners in a region of France. Int J Obes 29: 1100-1106.

18. Rand CS, Macgregor AM (1991) Successful weight loss following obesity surgery and the perceived liability of morbid obesity. Int J Obes 15: 577-579.

19. Anderson DA, Wadden TA (2004) Bariatric surgery patients' views of their physicians' weight-related attitudes and practices. Obes Res 12: 1587-1595.

20. Carr D, Friedman MA (2005) Is obesity stigmatizing? Body weight, perceived discrimination, and psychological well-being in the United States. J Health Soc Behav 46: 244-259.

21. Puhl RM, Andreyeva T, Brownell KD (2008) Perceptions of weight discrimination: prevalence and comparison to race and gender discrimination in America. Int J Obes 32: 992-1000.

22. Roehling MV, Pichler S, Bruce TA (2013) Moderators of the effect of weight on job-related outcomes: a meta-analysis of experimental studies: Effects of weight bias on job-related outcomes. J Appl Soc Psychol 43: 237-252.

23. Smith CA, Schmoll K, Konik J, Oberlander S (2007) Carrying Weight for the World: Influence of Weight Descriptors on Judgments of Large-Sized Women. J Appl Soc Psychol 37: 9891006.

24. Sitton S, Blanchard S (1995) Men's preferences in romantic partners: obesity vs addiction. Psychol Rep 77: 1185-1186.

25. Jackson SE, Steptoe A, Beeken RJ, Croker H, Wardle J (2015) Perceived weight discrimination in England: a population-based study of adults aged $\geq 50$ years. Int J Obes 39: 858-864.

26. Andreyeva T, Puhl RM, Brownell KD (2008) Changes in Perceived Weight Discrimination Among Americans, 1995-1996 Through 2004-2006. Obesity 16: 1129-1134.

27. Annis NM, Cash TF, Hrabosky JI (2004) Body image and psychosocial differences among stable average weight, currently overweight, and formerly overweight women: the role of stigmatizing experiences. 1: 155-167.

28. Carr D, Friedman MA, Jaffe K (2007) Understanding the relationship between obesity and positive and negative affect: The role of psychosocial mechanisms. Body Image 4: 165-177.

29. Hatzenbuehler ML, Keyes KM, Hasin DS (2009) Associations between perceived weight discrimination and the prevalence of psychiatric disorders in the general population. Obes Silver Spring Md 17: 2033-2039.

30. Vartanian LR, Shaprow JG (2008) Effects of weight stigma on exercise motivation and behavior: a preliminary investigation among college-aged females. J Health Psychol 13: 131-138.

31. Rosenberger PH, Henderson KE, Grilo CM (2006) Correlates of body image dissatisfaction in extremely obese female bariatric surgery candidates. Obes Surg 16: 1331-1336. 
32. Jackson SE, Beeken RJ, Wardle J (2015) Obesity, perceived weight discrimination, and psychological well-being in older adults in England. Obesity 23: 1105-1111.

33. Major B, Eliezer D, Rieck H (2012) The Psychological Weight of Weight Stigma. Soc Psychol Personal Sci 3: 651-658.

34. Sutin AR, Stephan $Y$, Luchetti M, Terracciano A (2014) Perceived weight discrimination and C-reactive protein. Obesity 22: 19591961.

35. Sutin AR, Stephan Y, Carretta H, Terracciano A (2015) Perceived Discrimination and Physical, Cognitive, and Emotional Health in Older Adulthood. Am J Geriatr Psychiatry 23: 171-179.

36. Sutin AR, Stephan $Y$, Terracciano A (2015) Weight Discrimination and Risk of Mortality. Psychol Sci 956797615601103.

37. Puhl RM, Heuer CA (2010) Obesity stigma: important considerations for public health. Am J Public Health 100: 10191028.

38. Ashmore JA, Friedman KE, Reichmann SK, Musante GJ (2008) Weight-based stigmatization, psychological distress, \& binge eating behavior among obese treatment-seeking adults. Eat Behav 9: 203-209.

39. Friedman KE, Ashmore JA, Applegate KL (2008) Recent experiences of weight-based stigmatization in a weight loss surgery population: psychological and behavioral correlates. Obes Silver Spring Md 16: S69-74.

40. Mora-Giral M, Raich-Escursell RM, Segues CV, Torras-Clarasó J, Huon $G$ (2004) Bulimia symptoms and risk factors in university students. Eat Weight Disord 9: 163-169.
41. Puhl RM, Moss-Racusin CA, Schwartz MB (2007) Internalization of weight bias: Implications for binge eating and emotional wellbeing. Obes Silver Spring Md 15: 19-23.

42. Schvey NA, Puhl RM, Brownell KD (2011) The Impact of Weight Stigma on Caloric Consumption. Obesity 19: 1957-1962.

43. Major B, Hunger JM, Bunyan DP, Miller CT (2014) The ironic effects of weight stigma. J Exp Soc Psychol 51:74-80.

44. Vartanian LR, Novak SA (2011) Internalized societal attitudes moderate the impact of weight stigma on avoidance of exercise. Obes Silver Spring Md 19: 757-762.

45. Jackson SE, Beeken RJ, Wardle J (2014) Perceived weight discrimination and changes in weight, waist circumference, and weight status. Obesity 22: 2485-2488.

46. Sutin AR, Terracciano A (2013) Perceived Weight Discrimination and Obesity. PLoS ONE 8: e70048.

47. Pomeranz JL (2008) A historical analysis of public health, the law, and stigmatized social groups: the need for both obesity and weight bias legislation. Obes Silver Spring Md 16: S93-103.

48. Puhl RM, Latner JD, O'brien KS, Luedicke J, Danielsdottir S, et al. (2015) Potential Policies and Laws to Prohibit Weight Discrimination: Public Views from 4 Countries. Milbank $Q$ 93: 691-731.

49. Puhl RM, Suh Y, Li X (2016) Legislating for weight-based equality: national trends in public support for laws to prohibit weight discrimination. Int J Obes. 